\title{
A EXPERIÊNCIA POÉTICA DE DANILO GIROLDO
}

\section{LA EXPERIENCIA POÉTICA DE DANILO GIROLDO}

\author{
Aimée Bolaños ${ }^{45}$
}

RESUMO: O presente artigo constitui uma leitura de viés hermenêutico do livro de poemas Vala (2019), de Danilo Giroldo. A análise está centrada tanto nos aspectos cosmovisivos como compositivos, com particular interesse nas categorias de metapoesia, metapoeta, enunciação metafórica e aberturas simbólicas. Inclui-se, ademais, um diálogo com o autor que aborda sua experiência criativa, motivações, destinatários, dimensões sociais, de modo que também se faz presente a voz e visão do poeta. As conclusões contribuem ao conhecimento da literatura atual brasileira desde a perspectiva crítica de uma obra, evidenciando elementos distintivos de sua poética em uma complexa representação da temporalidade histórica e do tempo humano na poesia.

Palavras chave: Poesia brasileira; cosmovisão; metáfora; poética.

RESUMEN: El presente trabajo constituye una lectura en clave hermenéutica del libro de poemas Vala (2019), de Danilo Giroldo. El análisis se centra tanto en los aspectos cosmovisivos como compositivos, con particular interés en las categorías de metapoesia, metapoeta, enunciación metafórica y significaciones simbólicas. Se incluye, además, un diálogo con o autor en el que es abordada la experiencia creativa, destinatarios, dimensiones sociales del poemario, de modo que también está presente la voz y visión do poeta. Las conclusiones contribuyen al conocimiento de la literatura actual brasileira desde la perspectiva crítica de una obra, profundizando en elementos distintivos de su poética en la compleja representación de la temporalidad histórica y del tiempo humano en la poesía.

Palabras clave: Poesía brasileira; cosmovisión; metáfora; poética.

${ }^{45}$ Doutora em Filosofia, rama da Literatura Latino-Americana - Rostock Universität, Alemanha. Pós-doutorado em Literatura Comparada pela Universidade Federal de Rio Grande do Sul-UFRGS. Professora do pósgraduação em Letras da FURG. Professora adjunta da Universidade de Ottawa. Escritora de ficção e ensaísta. 


\title{
$1 \mathrm{O}$ poeta na crise
}

\author{
O futuro é tão claro, \\ está por se fazer. \\ O sentido nunca foi tão evidente. \\ A ação tudo pode transformar. \\ "Noite e dia na mente" \\ Vala
}

Vala $^{46}$ irrompe como livro apaixonado e convulso, visionário e apocalíptico, de indagação subjetiva em sintonia discordante com seu tempo histórico. $\bigcirc$ poemário desenvolve uma abrangente visão originada na experiência, mas que vai além do pessoal. De modo poético a visão do entorno social, ético, natural, se comunica com afetos, sonhos, projeções do autor que assina o livro: Danilo Giroldo.

Seu livro é essencialmente inclusivo, de espaços do imaginário para compartilhar pensamentos, sensibilidades. Convivem a História e as estórias, só ao parecer menores. $\mathrm{O}$ poeta, tomando uma distância de si mesmo, interpreta sem moralismos nem intenção exemplar. Sabe-se, e assim o proclama, no olho da furação. Angústia, dor, incerteza, sideração, depressão estão em Vala; também suas contrapartidas: amor, solidariedade, esperança, beleza, humanismo, com a voz da poesia. $\mathrm{O}$ sujeito poético mostra sua fragilidade poderosa nas dúvidas e questionamentos, assim como nos desejos e prospecções. Em "Vida e morte" comovedoramente diz:

Que a tempestade me traga novas energias.

Faça-me voltar ao menos à sombra do que eu era.

Devolva-me ao rumo do qual me desviei.

E que os espinhos de vereda que passei,

com as paisagens que vi e as paisagens que vivi,

engrossem meu coro e ampliem minha visão,

pois sei que precisarei.

(p. 43)

\footnotetext{
${ }^{46}$ GIROLDO, Danilo. Vala. São Paulo: Patuá, 2019. Todas as citações pertencem a esta edição.
} 
O discurso de Vala é de perguntas que, dialeticamente, tem e não tem resposta. Quando os tempos vão se reencontrar? Você sabe quem de fato é? Como se livrar das marcas do caminho? Qual é o diâmetro do ponto de vista? O que fizeram com nossos sonhos? Por que não posso sonhar que tenho irmãos em Andrômeda? Em que momento meus montes de átomos passam ou deixam de ser eu? Possivelmente este conjunto relativo ao conhecimento, entre os mais dramáticos:
Qual é a realidade real?
Qual análise é mais fiel?
Qual percepção é mais precisa?
Qual é o caminho do coração?
O que leva ao abismo ou ao andar eterno e inútil?
(p. 24)

Grandes interrogantes voltadas ao indivíduo na reflexão metafísica tocam pontos cardinais de teor ontológico e epistemológico: o ser no conhecimento. Os temas maiores relacionam-se entre si para formar uma unidade plural que abrange tanto a existência no sentido filosófico como a historicidade de sujeito que assume sua crise.

No espaço autorreflexivo confessional, a metáfora do trauma está no centro de Vala. Em palavras de Boris Cyrulnik:

As dores psíquicas sempre acompanharam os seres humanos. Mas foram necessários séculos para ousarmos pensar a metáfora do trauma, no qual o impacto externo deteriora de maneira permanente o universo psíquico por um longo tempo. Atualmente, tem sido cada vez mais constante a evocação do conceito de resiliência para falar da capacidade de se refazer psiquicamente após um evento doloroso, para a retomada de um novo desenvolvimento após um traumatismo psíquico. (2013, p.1)

No fundo e na superfície, a crise tem múltiplos significados, pois não só alude ao sofrimento existencial, também implica autorreflexão, escolhas, transformação. Se apelarmos à etimologia, crise vem do grego krisis que significa separar, depurar, limpar, cujas raízes semânticas estão também em crisol e acrisolar. Bela metáfora conceitual o crisol, cheia de possibilidades realizadoras. Assim, crise sinaliza uma oportunidade de 
mudança; se certamente tem origem em um trauma, poderá ser regeneradora, de autopoiese ${ }^{47}$, processo árduo e até dolorido, se bem necessário, de autocriação na consciência do caos, assim como de produção de novos sentidos, no caso de Vala, em uma poesia atrelada à vida. Não por acaso a palavra resiliência, esse "nascer de novo" - no conceito de Cyrulnik - ecoa em todo o livro, até nas páginas mais desesperadas, como expressa o poema "Angustia" de modo lapidar:

O presente, resistência.

O legado, resiliência.

A mente estabilidade, não há!

A força regularidade, não dá!

Algum tempo só.

Tenha dó, não consigo.

[...]

Se for um ciclo, que acabe.

A paz enfim.

Por onde, não sei.

Mas vou encontrar. Será?

(p. 39)

Certamente no livro de Giroldo assistimos a uma formulação de problemas vitais: "Quando o apoio do ambiente permite uma elaboração da descrição de si, é possível observar uma retomada evolutiva dos estilos de apego." (CYRULNIK, 2013, p.1). Neste processo nada idílico da retomada de si que acontece no confronto com o mundo e consigo mesmo, vale recuperar ademais o conceito do agon grego, que originalmente significa luta sem fim e desafio. Assim Vala é livro de busca agônica, de produtivos choques, de contrastes gritantes que levam à

${ }^{47} \mathrm{O}$ conceito de autopoiesis (dos biólogos Humberto Maturana e Francisco Varela nos anos 70 de século passado) está referido ao funcionamento dos seres vivos com visão complexa, conceito de cognição inseparável do viver. Sendo pensando para nomear a condição dos seres vivos como autoprodutores de si mesmos, pelo seu valor teórico e pragmático, se expande a outros campos, destacadamente á literatura. 
postulação de outras formas de conhecimento e convivência na recuperação do apego a valores humanistas de justiça social.

Com consciência da crise, desestruturando fatalismos e quebrando paradigmas com a verdade da poesia, Vala rompe expectativas e alarga horizontes. Crise não significa imobilidade, pois localizar problemas é criar condições para resolvê-los e superá-los. De tal maneira, o autor se apresenta na obra mergulhando até o mais profundo de si. E não aludo só ao alto teor emocional do livro como testemunho de vida, também a seus julgamentos sociais que incitam à criação de novas bases democráticas, de consenso e participação na ligação com o imediato político. Desta maneira o livro, sendo tão de introspecção, acolhe vivências coletivas na aspiração ao melhoramento humano, motivação maior da poesia através de sua história.

No seio desta aspiração, a poesia de hoje - a de Danilo Giroldo, um estimável exemplo - apresenta um sujeito em processo, que se faz a si mesmo na instabilidade e no deslocamento; fluido, contraditório, evanescente, à semelhança da identidade líquida que postula Zygmunt Bauman, reveladora metáfora da modernidade tardia: "Os fluidos se movem facilmente. Eles 'fluem', 'escorrem', 'esvaem-se', 'respingam', 'transbordam', 'vazam', 'inundam” (2001, p. 8). Nesta referência é possível imaginar uma significação, entre outras, da metáfora da vala - conteúdo e continente - pela que correm os fluidos em contínuo movimento tanto de afirmação como de negação, preenchendo e esvaziando, imagem graficamente representada no texto, de jogo de palavras visual, que de modo dinâmico abre o livro (p. 7).

A condição humana do autor-personagem-eu poético, ocupa um lugar central em Vala, intimamente vinculada ao eu escritural. Quem fala na poesia atual? Como e desde onde? Eis interrogantes fundamentais que incitam a pensar em identidade esfacelada, rumo perdido, procura de sentidos, novos paradigmas. Os sujeitos da alta modernidade estão dilacerados na dramática busca de valores em uma sociedade que os está perdendo.

A visão, como Fernando Pessoa magistralmente caracterizara, é de "espanto, admiração, como de um ser tombado dos céus, a tomar plena consciência de sua queda, atônito diante das coisas" (1986, p. 37), o qual evidencia uma filiação poética que parte de romantismo e alcança um desenvolvimento extraordinário desde o simbolismo, Charles Baudelaire, grande mestre da tristeza pensativa. Esta angústia e dor existencial distinguem a uma considerável zona da poesia da alta 
modernidade. No contexto brasileiro, além de Augusto dos Anjos, Ana Cristina César, Murilo Mendes, Carlos Drummond de Andrade em Sentimento do mundo são figuras representativas. $\mathrm{O}$ signo comum poderia ser encontrado na figura do poeta que carrega em si os angustiosos tempos, como aparece neste fragmento do poema "Nada":

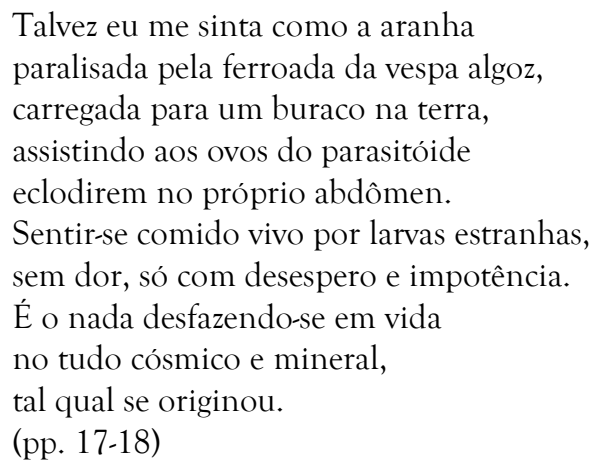

Desde o eu fraturado, o autor indaga na sua identidade biográfica, traça uma trajetória de vida e olha-se até alcançar uma representação de si, frequentemente na forma do autorretrato ${ }^{48}$ de mundo interior em agudo conflito com os referentes sociais. A subjetividade se objetiva a través de emoções, afetos, ideias, ideais, valores. O esboço autorreferencial é fragmentário, cada poema referido a fases, estados de ânimo e pensamento na vida do sujeito que finalmente se integra como totalidade imaginária, estruturando Vala. Visto de conjunto este autorretrato em movimento revela o dramático descenso às profundezas do ser e a ascensão, nada idílica, a uma espécie indefinível de luz que ilumina a reconstituição.

Nesta época pós-tudo, a poesia continua cultuando a palavra como comunicação humanizadora e modo de dizer o indizível, expressiva da subjetividade em crise que se abre ao outro, compartilhando buscas e saberes:

Eu andei bem mal.

Descrente de tudo.

${ }^{48}$ Ver o aportador estudo de Laura Scararo "Variaciones en la poesía última sobre el autorretrato". 
Sem esperança.

Sem vontade de levantar

para lutar a luta

que eu pensava estar lutando.

[...]

Agora ando melhor.

Voltei a sonhar.

Estou trabalhando.

Ocupado com afazeres.

Pequenas e grandes metas diárias.

Esperança da contribuição para o coletivo.

(p. 23)

Constitui-se no paradoxo do espetáculo íntimo instaurando novas formas de recepção, pois muda a perspectiva do leitor que é continuamente instigado a se reconhecer nas inconsistências, mas também nas tendências integradoras que estão já patentes na produção do poema, talvez esse "nada" de poema homônimo "desfazendo-se em vida" (p. 18) ou essa retomada no sonho coletivo (p. 23). Assim, longe do qualquer epílogo, tudo está começando a ser descoberto e, quiçá, transformado com a palavra poética que dá conta do eu nos turbulentos tempos atuais, orientação cosmovisiva que resulta muito patente em Vala como obra experimental e da experiência vital criativa.

\section{$2 \mathrm{O}$ poeta na poesia}

A poesia é minha ponte para o inconsciente, e dele emergem as respostas que a consciência por vezes, não quer aceitar. "Eu e os outros"

Vala

Compõem o livro três partes principais. Conjuntura: dor e reação; Espaço: presente e passado; Gente: origem e amor. Cada uma de estas partes une um conceito definidor e duas nomeações indicativas de conteúdos complementares alusivos à personalidade poética. Evidentemente a estrutura externa do livro, correspondendo aos grandes núcleos temáticos, sinaliza resistência e, ainda mais, resiliência, entendidas em sua relação orgânica. Nesse âmbito que vai da dor ao amor, o autor desdobra sua identidade atento à alteridade própria e 
alheia para se configurar como figura complexa, em crise e na busca, a qual promove a ação comunicativa.

O autor faz traça seu retrato escrevendo Vala porque a poesia constitui uma tentativa de contornar a angústia, ponte para o inconsciente e o simbólico, quem sabe se as respostas procurando uma forma emergente. Nesta ordem de pensamento, as categorias de metapoema e metapoeta resultam altamente expressivas. Em opinião de Víctor Zonano (2005-2006, p. 209), o termo de "metapoética" tem uma analogia com a concepção jakobsoniana da função metalinguística que se manifesta quando a linguagem concerne ao próprio código verbal. Então, em um texto "metapoético" a linguagem refere-se à poesia mesma, aos problemas inerentes a sua criação. Verónica Leuici (2012, p. 8) indica que se chamamos metapoema ao poema que se exibe como tal e revela seu caráter de artifício ou artefato, o metapoeta é o autor-poeta que se coloca na pele da personagem-poeta. Para Laura Scarano (2014, p. 43) o conceito de metapoeta é uma noção operatória para indicar que o eu lírico se identifica explicitamente com o poeta-autor na linha do correlato autoral.

$\mathrm{Na}$ metapoesia, a ficcionalização do autor-poeta faz dele uma personagem que atua no texto como figura discursiva. Transcendendo a visão romântica que iguala autor empírico e sujeito lírico, os entendimentos da poesia contemporânea consideram ao autor como uma função ou efeito do texto, diga-se Danilo Giroldo parte da ficção poética. Aqui vale lembrar que ficção não é antônimo de verdade, mas uma criação de imaginário. No conceito de Juan José Saer (2014, p. 16), uma espécie de antropologia especulativa, concepção muito patente em Vala.

Quem assina o livro, que não é quem existe, está também dentro do escrito como metapoeta característico de uma tipologia de poema que situa em primeiro plano a figura autoral. Na minha interpretação, o autor - com suas nuances, visões, temporalidades - desdobra-se no sujeito discursivo e vice-versa, verdadeiro jogo de espelhos. A figura autoral está explícita nos metapoemas, mas também disseminada no livro, concentrando e expandindo uma desafiante gama de significados que tem a ver com rasgos - físicos, profissionais, espirituais, de visão de mundo cuja referência é autobiográfica.

Os metapoemas são recorrentes, tematizando a poética, o processo criativo, os sentidos e formas compositivas referidas ao poeta-autor como figura imagética. Desde os primeiros poemas, sua imagem escrevendo alcança dimensão simbólica a partir do corpo da vida: "Pela ponta dos dedos o fluxo se dá" (p.13). Neste texto, significativamente titulado 
"Inspiração", no feche aparece a criação poética como catarse que sendo específica deste texto, subjaze nos estratos mais profundos de toda obra:

Enquanto houver dor, saudade e nostalgia, haverá versos de amor e esperança. Mesmo que a vontade seja curvar-se, enrolar-se e sumir dentro de si.

A poesia acalma a mente e o coração, ou seria impossível sobreviver.

Tal qual a Copaíba, secar e morrer de tristeza.

(p. 13)

Em "Biosfera cósmica", o poeta diz: "Traço um paralelo, livremente especulativo, que a poesia me permite" (p. 197). Nesse vínculo entre poesia e especulação encontra-se uma clave de poética. $\mathrm{O}$ autor pensa o mundo e a si mesmo na poesia. Nela mergulha no intento de compreensão, mas também de superação catártica da crise, a partir do reconhecimento das relações sociais alienantes, diferenciando a emoção conceitual da poesia "versos que se explicam por si" do discurso de retórica mais intelectualizada:

Tão fantásticas são essas reações físico-químicas.

Capazes de exceder a própria química e gerar dor e afeto, medo e esperança, amor e ódio, dúvidas sem conclusões. Incômodos gerados em camadas tão profundas, que produzem versos a se explicar por si, algo que nenhum ensaio faria melhor. (p. 125)

O processo criativo é de autorrealização, portanto liberador; funciona como terapia e bálsamo, estratégia de sobrevivência e, sobretudo, como outra forma de conhecimento, não importa duração nem alcance em relação ao longo inverno que se aproxima, nem ante a grande interrogante do futuro. Se algo caracteriza Vala é a renúncia às soluções fáceis, quiméricas. A tristeza vem entre "o primeiro e o vigésimo verso" que compõem o poema, mas também assoma a "breve esperança": 


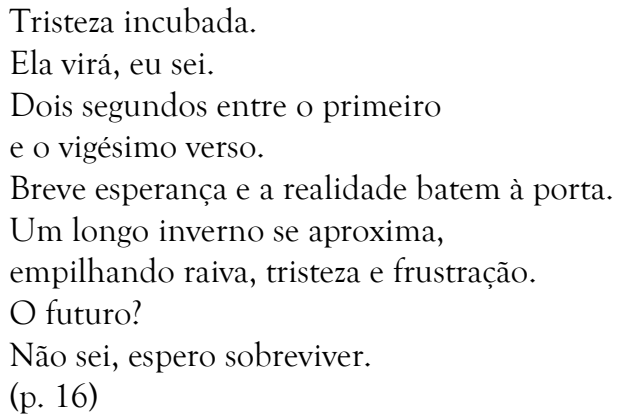

Nesse âmbito, o autor escreve porque vive sua poesia de encarnação vital, ela inspira e impulsiona nesse "caminhar pra frente" no sentido social e em consequência, humano. Para isso, cava em seu mundo interior, de turbulências e perplexidades a partir de um ponto de vista relativo à possibilidade de superação do individualismo na retomada de práxis comunitárias:

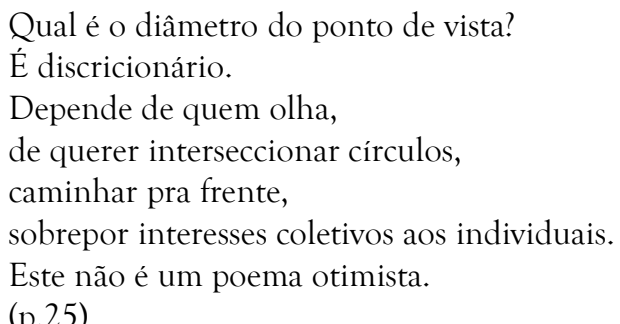

Ao procurar sustento nas genealogias, linhagens e filiações, tanto familiares como sociais e da natureza, encontra "uma crença na minha essência agnóstica” (p. 108). Expandida ao cósmico, a vida monofilética cria um elo entre uma espécie ancestral e seus descendentes, forma inédita de comunhão universal:

Se ao menos uma bactéria fosse encontrada em Marte, com ácidos nucleicos e síntese proteica, que alegria eu sentiria.

Deitaria no meu túmulo 
com um feliz sorriso

e em meu epitáfio estaria:

aqui jaz alguém que acredita

na monofilia da existência.

E que os memes de Dawkins

preservem, ao menos por um tempo,

esse evidente desatino.

(p.108)

Este metapoeta, ostensivamente biólogo, viaja no tempo e espaço, olha fora e dentro na procura de alicerces. Questões cardinais da história pessoal e social, do ofício, da família, das origens, assim como os espaços citadinos, a cultura material e espiritual de uma região tornam-se ancoragem. Ponto alto, a imagem da natureza do deslumbrante pampa costeiro:

Há de se ter reflexão e contemplação, pertencimento e atenção, para entender a beleza do pampa costeiro. E nem se fale das praias e lagunas infindáveis. Olhos habituados aos recortes montanhosos resistem a entender a etérea e eterna planície. Os alagados irregulares brotam sem sentido. Compõem um mosaico de cor e vidas múltiplas, diversidade que aflora no antes singelo campo. (pp. 74-75)

À plenitude natural, também ameaçada, que o circunda se opõe a miséria e injustiça reinante (patente nas imagens contrastantes das cidades), com inequívoca intenção de crítica. A natureza é representada na relação com o poeta como processo e não constância, no potencial espiritual da experiência desse mundo e de sua importância como espaço ainda incontaminado. $O$ falante em Vala quer traduzir pela palavra poética o caráter inefável do mundo natural, na união do corpo do poeta e o corpo infinito da natureza. Sua visão carrega a história humana e da pessoa na biosfera, denota uma ética ambiental que reconhece a responsabilidade política para com o meio ambiente. 
Nesta celebração da natureza, enquanto paraíso ainda não perdido, sobressai um poema como "Sananduva" que deixa ver o encantamento do poeta ante a beleza do reino natural, fonte de vida:

Erytrina crista-galli.

Quando o nome científico é poesia.

Cortiçera do banhado.

Quem conhece não esquece o espetáculo.

[...]

Quando te veem sem folhas, só com o caule e os galhos, podem pensar que morreu, mas tal qual a corticeira, vais renascer, e será com a força do mais intenso vermelho. (pp. 78-79)

Os saberes sensíveis permitem olhar e descrever desde uma flor até a vala que, por fim, poderá se tornar "amuleto de vida" (p. 128). E dentre os saberes, distingue-se o poético porque, caso contrário, não estaríamos falando de poesia. Em tal sentido, é notável a variedade de registros: coloquialismo, concretismo, efeitos de oralidade, lirismo. Também a diversidade das formas enunciativas que poderão ser de síntese conceitualimagética ou de mais extenso fôlego argumentativo. E, em todos os poemas, uma sintaxe nada convencional, atenta às potencialidades da linguagem e marcadamente experimental: jogos de palavras, conceitos ao avesso, troca de significados, polissemia, rupturas de sistema, argumentos e contra-argumentos, afirmações que contém sua própria negação, salutar relativismo, todas estas modulações fazem possível a fluência livre do pensamento na riqueza da expressão poética.

Em Vala o significado oscila, está sendo e deixando de ser, a velha e sempre nova sabedoria dialética contraposta às oposições binárias. Os significados são movediços, a desvendar na função leitora, de modo que se correspondem composição e visão. Repare-se, por exemplo, nesta imagem inicial de "(Re)Evoluções em espiral", a partir da qual se desenvolverá um extraordinário poema de simbiose metafórica entre o observador e o observado: 
Atônito observo as espirais.

E, espiralmente, movimento-me, perdendo a referência e a direção.

Busco conduzir a rota, analisar a trajetória, incapaz de saber o que restará depois que os furações passarem. (pp. 66-67)

\section{$3 \mathrm{O}$ metaforismo no poesia de Vala}

Você pensa que está fora, mas está mais dentro que nunca.

"Sonhos de mudança"

Vala

Um lugar muito criativo ocupa o metaforismo e suas derivações simbólicas. Flor, planta, planície, mar, gema, nada, cinza, buraco, brete, espiral, anteparo, casa em demolição, fora, dentro e sempre vala, na composição viram metáforas vivas, de invenção, que categorizam o mundo porque levam em si uma forma de conhecimento pelo olhar da poesia. Repare-se na efetiva síntese de metapoema e enunciação metafórica:

Os versos correm

como a água desce o monte.

Às vezes fortes como corredeiras, outras vagarosos feito remansos.

Aliviam a pressão e desaguam no papel.

Não tarda e outra tempestade virá, agitando moléculas na mente do poeta.

Nova tromba d'água está por vir.

Tantas quantas forem as injustiças.

(p. 13)

O singular tecido metafórico de Vala faz possível outra lógica, tão ambígua como eloqüente. Certamente ao invocar a metáfora de criação, impossível não pensar em Paul Ricoeur quem reformula o conceito, fundamentalmente em A metáfora viva (1975), mas muito presente em sua obra, ao refletir sobre o sujeito do tempo humano na poesia 
contemporânea. Na teoria de Ricoeur a imaginação aparece como síntese constitutiva dessa identidade cheia de nuances que implica novos horizontes cognoscitivos e maneiras de estar no mundo.

$\mathrm{Na}$ teoria da poesia o vínculo entre imaginação e metáfora é fulcral. Ricoeur considera que a imaginação produz sentido, no fundamental, pelo uso metafórico da linguagem. Distinguem-se estes enunciados metafóricos pela atribuição predicativa transgressora que integra campos semânticos heterogêneos e nem sempre compatíveis, estabelecendo outras formas de parentesco. As metáforas de criação, como notavelmente aparecem no livro de Giroldo, trazem consigo, além da inovação semântica, efeitos de ressonância, reverberação, eco. Elas geralmente formam redes coerentes a partir de uma que funciona como matriz. Contudo, é imaginação a que regula a impertinência semântica e oferece novas pertinências. A mediação do imaginário faz emergir os significados.

Para Ricoeur, portanto, a imaginação cria visões de mundo: "Aperceber, contemplar, ver o semelhante, tal é no poeta, é claro, mas também no filósofo, o golpe de gênio da metáfora que reunirá a poética à ontologia" (2000, p. 4). O poeta é um artífice que engendra e configura imagens, cuja verdade não é literal, mas metafórica, na suspensão da referência de primeiro grau - o brete, a orquídea - que remite a uma segunda, não necessariamente realista nem irreal, se bem expressiva da "nossa pertença profunda ao mundo da vida", assim como da "ligação ontológica do nosso ser aos outros seres e ao ser." (RICOEUR, 1989, p. 220). Este vínculo essencial entre poética e ontologia, entre poesia e conhecimento, implica outra proposta do conceito de metáfora - para a preceptiva tradicional só ornamento como figura da linguagem -, aporte da maior relevância de uma linha de pensamento que vem de Aristóteles a Ricoeur e nos últimos anos desenvolvida pela poética cognitiva ${ }^{49}$.

Unida à teoria da metáfora, Ricoeur adentra-se no símbolo. De tal modo, sua hermenêutica defende o valor filosófico do símbolo para o conhecimento do ser e do mundo, suas potencialidades de reconfiguração da multiplicidade de significados que se integram como visão de mundo. Em contraposição à ideia do esvaziamento de sentido patente em uma zona considerável do pensamento pós-moderno, na interpretação de

${ }^{49}$ Ver George Lakoff e Mark Turner: More than Cool Reason. A Field Guide to Poetic Metaphor, especialmente o segundo capítulo "A Power of Poetic Metaphor", pp. 57-139. 
Ricoeur o símbolo dá sentido, dá "que pensar". Mas também nele "tudo está dito em enigma", portanto é preciso começar e recomeçar na dimensão do pensar (1991, p. 283). Neste sentido, possivelmente as irradiações simbólicas da metáfora seminal da vala, que recorre todo o livro e lhe dá nome, uma das mais desafiantes pelas múltiplas conotações.

Então, vale reparar nesse rico caudal imagético que distingue o discurso poético de Giroldo. Em "Soneto a uma flor" (p. 41), à pergunta de "Qual seria a flor que melhor representaria minha dor", as respostas são pensadas de modo metafórico, em uma imaginativa invenção atrelada ao sentimento. Neste soneto, o poeta coloca algo novo, que embora já esteja, será percebido de outra forma, neste poema na alusão ao difícil viver: o cravo da despedida, a rosa despedaçada, a violeta a definhar, a orquídea paradoxal que ao encontrar seu propósito, perde o brilho insólito.

Como postula a poética cognitiva (LAKOFF \& JOHNSON, 1980), as metáforas vão além da gramática ou léxico. Ler uma metáfora implica reconhecer dois domínios cognitivos, portanto, conceituais: o domínio origem de natureza experiencial e o domínio alvo de caráter simbólico e significados abertos que institui um conjunto de possibilidades relativas ao imaginário do autor, da história da poesia e da historicidade que sustenta a própria metáfora. Assim em Vala e no contexto da violência cotidiana, com explícita consciência metapoética, a figura autoral assume ironicamente a voz do opressor: "Cale-se ou vai virar peneira./ Literal ou metaforicamente” (p. 58). A relação entre o domínio origem (a peneira) permite compreender pela via da imaginação o domínio alvo, criação de leitor, motivado pela proposta autoral.

Desta maneira também aparece em "Buraco", com sua efetiva enunciação metafórica que articula o discurso a nível simbólico. Este texto, pela sua natureza performática (instruções para cavar um buraco), demanda participar em uma ação que tem varias camadas de significados. A interpretação vai do literal (domínio origem) ao simbólico (domínio alvo) e vice-versa em um movimento que apela à experiência de quem lê se perguntado, além do obvio, o que é um buraco. Instigante e desestabilizador, o poema finalmente avisa:

\footnotetext{
A quem possa interessar:

se for cavar um buraco, não esqueça de deixar uma corda, presa na superfície,
} 
para fugir ou se enforcar, quando perceber que o buraco é só um buraco, e não há nada a procurar. (p. 45)

Sem dúvida, a poesia pode estremecer, desafiar, transformar nossos esquemas de conhecimento. Em Vala o pensar metafórico é encorpado, imaginativo, cognitivo e, principalmente, expressivo do processo de constituição desse pensamento, mostrando ao sujeito interatuando com o mundo de uma maneira nada convencional. Sendo do sistema conceitual relativo ao modo como compreendemos e orientamos nossas ações, a metáfora tem, ademais, teor emocional. Desta forma, diz algo muito importante sobre criatividade, porque ao passar de um domínio mais conhecido a outro por imaginar, configuram-se assim novos significados que incentivam a imaginação leitora. Entendemos os enunciados metafóricos porque temos referencias comuns. Seus processos criativos não são tradicionais transferências ou translações de sentido, porém um fenômeno conceitual que funciona dentro de um modelo cognitivo. Não só uma forma de expressar, mas de pensar, de compreender o mundo. Precisamente nesta concepção, o metaforismo de Vala torna-se altamente ilustrativo.

Como livro de pensamento e da afetividade, de perguntas físicas e metafísicas, de inquietações éticas e políticas, a metáfora e o símbolo conceituam sem doutrinar, propiciando a livre interpretação que une autor e leitor na busca de sentidos. Questionar, imaginar, interrogar, criticar, propor mundos alternativos, tudo faz parte de Vala, livro corajoso que exibe sua primeira pessoa cavando a fundo para deixar em aberto. Ferida e fenda, buraco e leito de rio, cova e canal das águas vivificantes e muito mais pode ser vala na imaginação poética: "barreira, repositório, reservatório" (p. 128). Sobretudo a metáfora de vala fica aberta ao desconhecido. No hermetismo e transparência de seus símbolos, Vala incita a leituras de imprevisíveis ressonâncias, especialmente quando o leitor entrega-se às fulgurações da poesia no vislumbre de que "o modo simbólico estará lá onde finalmente tivermos perdido a vontade de decifrar a qualquer custo". (ECO, 2003, p. 143)

Além da polaridade simplificadora de otimismo e pessimismo, ao entender que a morte faz parte da vida e não é exatamente seu oposto, escavando simbólica e metaforicamente na crise, o livro de Danilo Giroldo pensa no seio dos paradoxos, atua no poético indefinível, 
aprofundando nos conflitos do conhecer e fazer, sem escolhas fechadas. Neste espírito, e desde nossas angústias, frustrações e desatinos históricos, talvez possamos criar alternativas sociais e humanas, tão difíceis como promissórias.

\section{Diálogo com Danilo Giroldo sobre Vala}

Aimée G. Bolaños (AGB): Como foi a experiência criativa de Vala? Quais foram tuas motivações principais? Como foi se colocar no meio da crise e falar sobre ela poeticamente? Qual é tua posição sobre autopoiese e resilência na poesia?

Danilo Giroldo (DG): Vala nasce do inconformismo e da sensação de desajuste em relação ao mundo real. Esse sentimento me acompanha há muito tempo. Toda a compreensão de mundo e sociedade que venho formando desde a adolescência é revestida de um profundo desconforto com a percepção da realidade. Deste inconformismo emerge uma projeção, que cada vez mais percebo como utópica, de uma realidade idealizada e possível de ser construída. Esta projeção determinou meu comportamento como cidadão e me aproximou, também desde cedo, de lugares e espaços de tomadas de decisão e gestão, ao ponto de me levar à Reitoria da FURG. A posição de Pró-reitor, e depois de Vice-reitor, me possibilitou colocar muitos dos meus sonhos em prática e os tornar realidade coletiva. Mas eis que a conjuntura política e social muda drasticamente em pouco tempo, emerge o fascismo, neo-fascismo ou qualquer coisa semelhante que ainda não sabemos caracterizar com o devido distanciamento e precisão. Desaparece qualquer possibilidade de construção de consensos e se aprofunda no nosso território uma crise social sem precedentes com a desestruturação da indústria naval. Esse contexto me decepciona profundamente, surge um sentimento de imensa impotência e, após uma séria lesão no joelho, as dores surgem de todo o lado com uma intensidade que eu ainda não havia vivenciado. Ou seja, o desajuste em relação à realidade supera qualquer limiar que eu já tenha experimentado e abre-se uma Vala em mim, como retrata o Colofão na última página do livro. Caracteriza-se a crise e a expressão em versos foi a forma mais precisa de representar e, ao mesmo tempo, aliviar as dores que chegaram a níveis insuportáveis. Vala, dessa forma, é também um registro de como o surgimento do neo-fascismo brasileiro atingiu e influenciou alguém em posição de gestão e que fazia da construção de consensos o seu dia a dia. 
O meu encontro com a obra de Maturana é recente, mas potente e também coincidente com o meu processo criativo. Quero me aprofundar mais em seu pensamento e obra, mas o pouco contato que tive já foi como se eu o tivesse lido há muito tempo e como se ele tivesse influenciado muito da minha visão de mundo e sociedade. Somos ambos biólogos, o que produz uma percepção muito particular. Acho que a teoria da autopoiese é válida para compreender muito do comportamento dos seres vivos, especialmente em relação ao efeito do meio na capacidade de autoprodução e autorregulação dos seres. A poesia é, portanto, na minha visão, um exemplo fantástico de comportamento autopoiético, quando se torna manifestação do efeito do mundo exterior sobre os sistemas nervosos humanos e também atua para autorregulá-los. A resiliência, da mesma forma, se torna produto destas flutuações no meio exterior e suas influências sobre a nossa percepção. Ou seja, poetizar é uma forma de resistir às perturbações externas que afetam nossos sentimentos, de modo a conferir resiliência ao nosso ser contra estas próprias perturbações.

AGB: Como te autodefines? Que relação existe entre o autor e o sujeito poético do livro?

DG: Creio que sou um sujeito que luta diariamente contra essa sensação de desconforto com o mundo exterior. $O$ presente é fundamentalmente ruim, o futuro bom e utópico, dependente, portanto, da esperança. Isso não significa que eu não valorize os prazeres diários individuais. Eu os aproveito intensamente como forma de suportar o incômodo com o ambiente coletivo. Não deixo de amar, de me alegrar com as pequenas conquistas diárias, de sentir os efeitos das endorfinas produzidas com o esporte e com o convívio social que me fazem, sim, ser uma pessoa intensa em todo o meu fazer e majoritariamente alegre. Porém, um sujeito que convive paradoxalmente com uma tristeza profunda com o ambiente coletivo degradado. Assim, creio que o meu sujeito poético representa muito mais o desconforto com o ambiente coletivo, do que com os meus prazeres individuais. Muitas pessoas me procuram preocupados comigo depois de ler meus versos e eu procuro dizer que aquilo é uma parte de mim, não o meu todo. Ou seja, autor e sujeito poético tem bastante aderência, mas ela não é total, pois só parte de mim se expressa nos versos. 
AGB. Como dialogam poesia, ciência, ética e política?

DG: No meu processo criativo o diálogo é intenso. De todas as formas que eu já experimentei para propor este diálogo, a poesia é de longe a mais eficiente. Consegui expressar sentimentos e ideias presos há muito tempo dentro do meu peito e do meu cérebro. Posso citar os exemplos de "Ode ao micróbio pioneiro", "Biosfera cósmica" e "Eu e os outros" como expressões deste diálogo. A biologia e, especialmente, o evolucionismo, são formas particularmente interessantes para discutir ética e política, permitindo que se debatam comportamentos e adaptações humanas de uma perspectiva pouco usual, mas muito interessante e disruptiva. Penso que esta é uma contribuição que a minha obra poética ousa trazer.

AGB: Como caracterizarias tua poética? Que é para ti a poesia? Por que os metapoemas e o metaforismo? Especialmente a metáfora de vala, que sentidos poderia ter?

DG: Eu ainda tenho dificuldade para caracterizar a minha poética. Tenho recebido impressões e discutido com parceiros, mas não sei se tenho distanciamento suficiente para fazê-la adequadamente. Creio que, no máximo, consigo dizer que ela é fortemente influenciada pela minha percepção e reações em relação ao mundo exterior. Além disso, a forma com que me expresso poeticamente é pela construção de metáforas, que talvez sejam absurdas para muitos que me lêem, mas representam a percepção do mundo exterior pelo meu sujeito poético. Penso que o metaforismo é muito marcante na minha produção literária, talvez por promover um certo distanciamento entre sentimento e palavra. Percebo que esse afastamento é importante para estimular a cognição a resignificar a forma mais pura do sentimento.

Quanto aos metapoemas, penso que eles são parte da minha própria tentativa de compreender o processo criativo que se desencadeou de forma intensa. A criação de um poema se dá de dentro para fora, em um processo intuitivo e, muitas vezes, até inconsciente, revelando impressões, análises e sensações antes escondidas pela racionalidade.

"Vala" é uma metáfora de muitos significados. Creio que a maioria deles está expressa em diferentes poemas do livro. Copio abaixo o Colofão que creio responder um pouco dessa questão:

Em 2018, uma vala se abriu em mim, dentre tantas que já existem no mundo. 
Vala é barreira, às vezes quase intransponível.

Vala é repositório.

Vala é reservatório.

Vala é desconhecido.

Dor, frustração, fracasso e impotência

acumularam-se no meu peito.

Subiram para a garganta.

Não saíram pela boca.

Foram direto para o cérebro e lá se alojaram.

Quando a dor física veio,

a vala se abriu.

Saiu tanta coisa dela,

e ainda sai,

que é difícil compreender.

Já não quero mais entender,

só ler e escrever,

escrever e ler.

A dor amansou,

a indignação nem tanto.

Vala agora é um amuleto,

cuidado com muito carinho.

AGB: Como imaginas teu leitor? Que gostarias que chegasse a teus destinatários? Hoje, que o livro tem vida própria, como te relacionas com ele?

DG: Este tem sido um exercício interessante que tenho me dedicado mais recentemente, imaginar e tentar compreender o meu leitor. Também não é tarefa fácil e ela não é um pressuposto para o meu processo criativo. Eu imaginava que interessaria a leitores com sentimentos, dores e impressões do mundo semelhantes as minhas, mas a prática não tem confirmado isso. Tenho visto leituras tão diversas quanto interessantes dos poemas que estão no livro, de modo que esse exercício de imaginação serve mais como aprendizado sobre o meu sujeito poético, do que propriamente uma fonte de inspiração no processo criativo. Por outro lado, a poesia é uma potente forma de comunicação e percebo que intenciono comunicar que é preciso ressignificar a realidade coletiva a partir do nosso papel individual na sociedade (soa bem Belchior isso). Creio que busco também representar a avaliação de que esta realidade coletiva não é boa, tampouco a atuação individual em busca de um futuro coletivo. De alguma maneira, demonstrar que é possível um futuro 
coletivo mais justo, construído inclusive a partir da rede de afetos que desenvolvemos por lugares e pessoas durante nossas vidas.

O meu relacionamento atual com o livro é conflituoso, muito variável e volátil. Tem dias que estranho e detesto as palavras que compõem os poemas, outras vezes elas voltam a produzir em mim o mesmo sentimento que aflorava no momento da escrita. Mas, ao cabo, tenho sempre a certeza que a escrita e publicação deste livro me tornou um ser humano melhor.

\section{REFERÊNCIAS}

BAUMAN, Z. Modernidade líquida. Rio de Janeiro: Jorge Zahar, 2001. CYRULSKI, B. Resilência: nascer de novo. 2013. Disponível em: <https://www12.senado.leg.br/institucional/programas/primeirainfancia/artigos/artigos-ano-2013-1/resiliencia-nascer-de-novo-boriscyrulnik-ano-2013> Acesso em: 29 junho, 2019.

ECO, U. Sobre a Literatura. Rio de Janeiro; São Paulo: Record, 2003. GIROLDO, D. Vala. São Paulo: Patuá, 2019.

LAKOFF, G.; TURNER, M. Metaphors We Live By. Chicago: Chicago University Press, 1980.

LAKOFF, G.; TURNER, M. More than Cool Reason: A Field Guide to Poetic Metaphor. Chicago: Chicago University Press, 1989.

LEUCI, V. Poesía y autoficción: una alianza posible. In: Congreso Internacional de Teoría y Crítica Literaria Orbis Tertius, VIII. Memoria académica del Centro de Estudios de Teoría y Crítica Literaria. Facultad de Humanidades y Ciencias de la Educación, Universidad Nacional de La Plata, La Plata, 7, 8, y 9 de mayo, pp. 5-14, 2012. Disponível em: <http://www.memoria.fahce.unlp.edu.ar/trab_eventos/ev.2356/ev.2356. pdf> Acesso: 5 agosto, 2019.

PESSOA, F. Obras em prosa. Rio de Janeiro: Nova Aguilar, 1986.

RICOEUR, P. Do Texto à Ação. Ensaios de Hermenêutica II. Porto: Rés, 1989.

RICOEUR, P. O si mesmo como o outro. Campinas: Papirus, 1990.

RICOEUR, P. A metáfora viva. São Paulo: Loyola, 2000.

SAER, J. J. El concepto de ficción. 4a ed. Buenos Aires: Seix Barral, 2014.

SCARARO, L. Vidas en verso: autoficciones poéticas. Santa Fe: Ediciones Universidad Nacional del Litoral, 2014. 
SCARARO, L. Variaciones sobre el autorretrato en la poesía última. Versants. Revista suiza de literaturas románicas, vol. 3, no 64, pp. 13-22, 2017.

ZONANA, V. G. El rabdomante sagrado, texto metapoético de Jorge Enrique Ramponi. Piedra y Canto. Cuadernos del CELIM, no. 11-12, pp. 219-229, 2005/2006.

Recebido em: 22/08/2019

Aceito em: 14/09/2019 